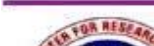 \\ AD SPCRD GLOBAL PUBLISHING

\section{How do Climate Change, Environmental Degradation and Economic Growth affect CropsProduction in Pakistan?}

\author{
a Imran Sharif Chaudhry, ${ }^{\mathrm{b}}$ Abdul Rehman Aslam, ${ }^{\mathrm{c}}$ Fatima Farooq, ${ }^{\mathrm{d}}$ Muhammad Faheem \\ ${ }^{a}$ Dean of Arts \& Social Sciences / Professor, School of Economics, Bahauddin Zakariya University, Multan, \\ Pakistan \\ Email: imran@bzu.edu.pk \\ ${ }^{\mathrm{b}}$ M. Phil Scholar, School of Economics Bahauddin Zakariya University, Multan, Pakistan \\ Email: abdulrehmanaslam6811@gmail.com \\ ${ }^{\mathrm{c}}$ Associate Professor, School of Economics Bahauddin Zakariya University, Multan, Pakistan \\ Email:fatimafarooq@bzu.edu.pk \\ d Assistant Professor,School of Economics, Bahauddin Zakariya University, Multan, Pakistan \\ Email: faheem@bzu.edu.pk
}

\begin{tabular}{l}
\hline ARTICLE DETAILS \\
\hline History: \\
Accepted 29 October 2021 \\
Available Online December 2021
\end{tabular}

Keywords:

Climate Change, Global

Warming, Government Economic

Policies, Production

JEL Classification:

Q54, Q10, O4O, C22

DOI: $10.47067 /$ ramss.v4i4.199

\begin{abstract}
Climate change has become one of the most imperative problems of this century. Climate change is a grave global threat, and Pakistan has been ranked eighth on the list of countries most vulnerable to climate change by the German watch Global Climate Risk Index. The increasing amount of carbon dioxide ( $\mathrm{CO}_{2}$ ), the foremost contributor to environmental degradation, seems to provoke this problem. Agriculture-based economies have always been dependent on the vagaries of nature and climate. Present study analyses the climate change, environmental degradation, input index and economic growth impact on crops production in Pakistanfrom 1977 to 2016. Our study employsAuto Regressive Distributed Lag Model (ARDL) to check the long run association among the variables. The results shows that positive association among climate change and crops production in the longrun.On the behalf of results policymakers must drive attention to adopt advanced cultivation processes using farming practice through international research institutions' assistance to further improve crops production in Pakistan.
\end{abstract}

(C) 2021 The authors. Published by SPCRD Global Publishing. This is an open-access article under the Creative Commons Attribution-

NonCommercial 4.0

Corresponding author's email address: faheem@bzu.edu.pk

\section{Introduction}

From the last two decades global humanity facing a multi-complex problem that is known as climate change.Climate change events may vary from country to country, andno country is free from it(O’Neill, et al., 2020).The atmospheric situation that prevails for some days is known as weather 
while if these circumstances conquer intended for a season, decade, or century known as climate(Bucchignani, et al., 2021). Climate change influences agriculture production through temperature and precipitation (WB, 2008; Anderson, et al., 2020). Climate change positively or negatively influences the agriculture sector variesfrom crop to crop and region to region (Aaheim et al., 2012; IPPC, 2014; Dellink, et al., 2019). Climate change is a mere threat as rich countries are thinking; rather, it has negative effect on economic growth(Johnsson et al., 2019). The climate conditions are closely related to agriculture output and can dramatically reduce it (Raza et al., 2019). Developing countries like Pakistan, India, and Bangladesh are more climate-sensitive than developed countries; they cannot cope with climate susceptibility because they do not have advanced technology and better adoption change (Shakoor et al., 2011).

Pakistan entails arid and semi-arid areas: inthe previous century, average temperature and precipitation increased $0.6{ }^{\circ} \mathrm{C}$ and 25\% all over Pakistan. During 2000-2012 average temperature stood at $0.7^{\circ}$ cofwhich was higher than 1985 to 1999(GOP, 2017).Figures 1 and 2 display the growth rate trend of average annual temperature and rainfall.

Fig. 1 Average Annual Temperature Growth Rate Graph

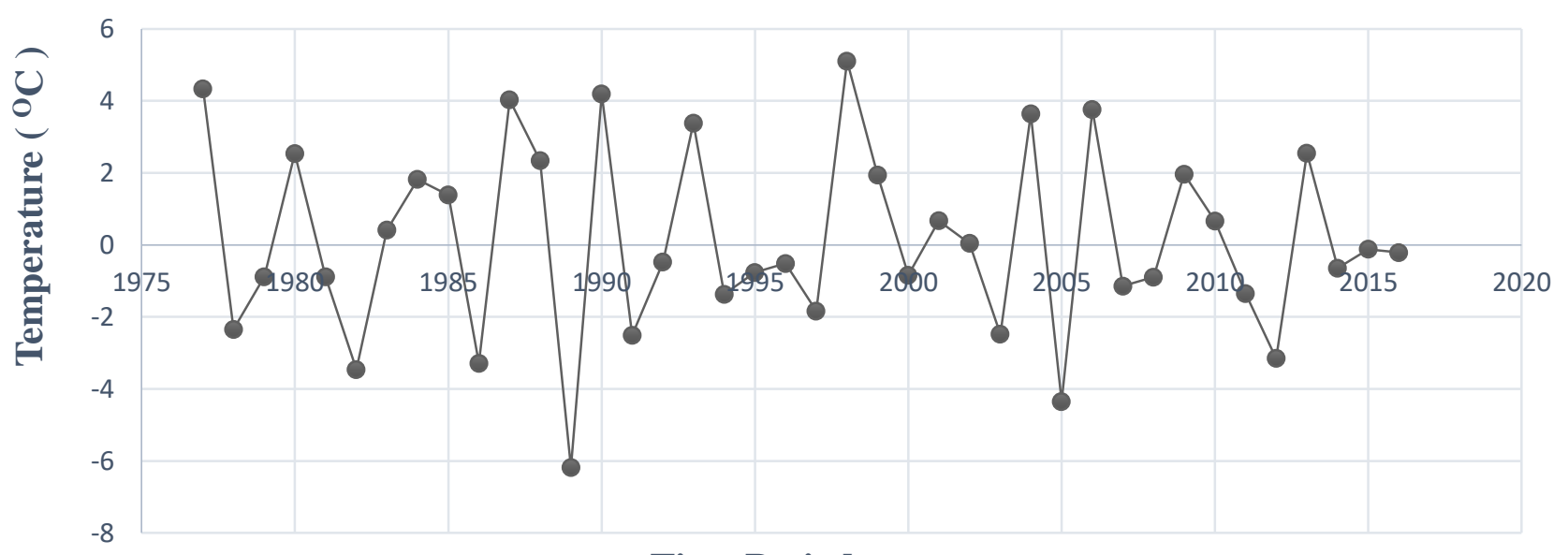

Time Period

Source: Author's Contribution

Fig. 2

Average Annual Rainfall Pattern Growth Rate Graph

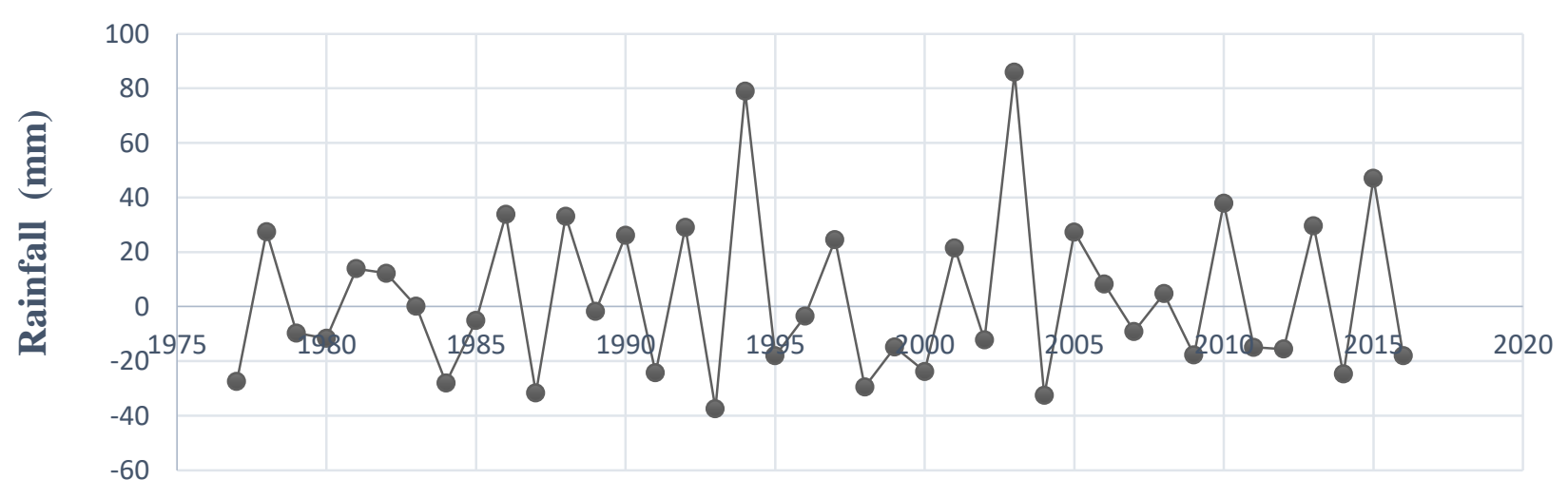

Time Period 
Source: Author's Contribution

Projections made by the Global Change Impact Studies Centre (GCISC) indicate that the average temperature over Pakistan would increase in the coming decades at a pace faster than the average global temperature and may even exceed it by $1^{0} \mathrm{C}$ at the end of the century.( GoP, 2013, p.244).

Agriculture is the cornerstone of Pakistan's economy and a major source of gross domestic product, unfortunately, this sector is going backward since its inception. The agriculture sector provides foods to living beings and the secondary sector attains fiber from cotton. However, it contributed 19.5\% in gross domestic product and $43.5 \%$ labor force employed in it (GOP, 2017). As human beings, we cannot separate ourselves from nature, and while living in Pakistan, we cannot detach ourselves from it.This sector progression is linked with weather and climate circumstances like drought, flood, temperature, and rainfall pattern which negatively influences production and prices. Agriculture production plays a key role in poverty alleviation. A stable agriculture sector ensures food availability for the livelihood of a country. Figure 3 shows the Crops production growth trend.

Fig 3 Crops Production Growth Rate Graph

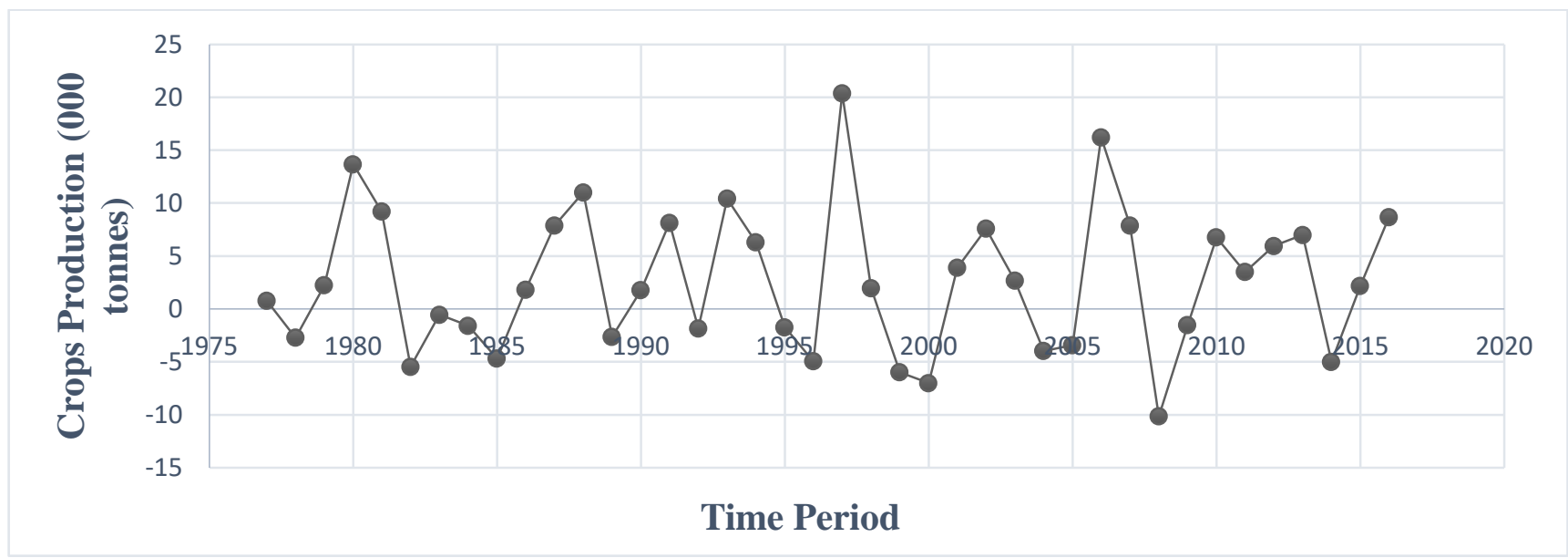

Source: Author's Contribution

Agriculture production is influenced by rainfall patterns, temperature variation, water accessibility, land suitability, evapotranspiration ${ }^{1}$, vagaries sowing, and harvesting dates. (Harry et al., 1993). The agricultural sector is based on non-supporting weather circumstances irrigation systems besides soil quality and other inputs (Gornall et al., 2010). Deviation in climate variables (temperature and precipitation) hasan enormous impact on crop production (Calzadillaet al., 2014). Temperature and rainfall are known as the direct largest inputs influencingagriculture production (Akram and Hamid, 2015).

Environmental degradation is themost debating concern of this centurycarbon dioxide $\left(\mathrm{CO}_{2}\right)$ is a major contributor to it which is increasing over time (Kirikkaleli, et al., 2021). Men play a pivotal role in increasing the carbon-dioxide concentration in the atmosphere; before industrialization, its amount was 28oppm2 (Hashimoto K., 2019). It rises by 380ppm because of fossil fuels' enormous

1The sum of evaporation and plant transpiration from the surface of the earth to the atmosphere.

$2 P P M$ means parts per million. It is used to measure the level of pollution in the air. It is a ratio between pollutant components and the solution. 
practice besides deforestation. Carbon dioxide playsa pivotal role in the greenhouse gas effect (Ifeanyi-obi et al., 2012). Carbon dioxide progressively influences plants through two channels. The first one is a rise in the plant's photosynthesis process, which is noticeable in $\mathrm{C}_{3}$ crops. The second one is that the rising concentration of carbon-di-oxide in the atmosphere reduces the transpiration 3 due to incompletely close by stomata and deterioration in water loss of plants. Both features improve the efficiency of plants refers tothe escalation of growth. Intensification of the level of carbon-dioxide illustratesthe progressive influence on plant growth. (Marocoet al.,1999; Admaset al., 200o). The immense amount of carbon-di-oxide in the atmosphere alludes to an escalation of water consumption efficiency, crops growth and vastly upsets water availability (Gedney et al.,20o6; Long et al.,2006 and Betts et al., 2007). Economists are concerned about climate change and environmental quality in the economic framework because it has been observed that these are importantconcerns for the agriculture sector andpolicy-makingof a country.

\section{Review of Empirical Studies}

Warrick (1988) examined the influence of carbon-di-oxide and climate trends on the agriculture sector. The researcher accessed a huge concentration of carbon-di-oxide in the atmosphere to increase water efficiency by transpiration in $\mathrm{C}_{3}$ Crops in a particular wheat crop. The researchvalidated that if the concentration of carbon-di-oxide doubles in the atmosphere, it will increase 10 to 50\% of wheat production in the mid and high-latitude regions of Europe and America. Variation in temperature and precipitation refers to a 3-7 \% decline in wheat production.

Hanif et al. (2010) quantified the negative economic impact of climatic changeon major crops in Punjab. This study concerned agrarian economies directly interconnected with weather conditions and agriculture regions affected by rainfall variability and temperature variability. Janjua et al. (2010) researched the influence of climate change on wheat production in Pakistan. This research highlighted that industrializationis the key factor for global warming sincepre-industrialization carbon dioxide emission is less than as compared topost-industrialization. The study concluded that climate change has not threatenedwheat production in Pakistan.

Shakoor et al. (2011) traced the effect of climate change on the agriculture sector in the arid region. The study found that a $1 \%$ and $8 \%$ rise in temperature and rainfall would cause a loss of 4180 rupees per annum and an increaseof 377 rupees, respectively. The adverse temperature impact is higher than positive rainfall effects. Siddiqi et al. (2012) rendered the climate change effect on four major crops in Punjab. The temperature riseis beneficial for wheat productivity in the long run but harmful in the short run while rising in precipitation is valuable in both periods. The increase in temperature is positive for rice crops just inthe first stage, but afterward, it is damagedconversely, the rise inprecipitation has noadverse effect on cultivation stages. This study further elaborated that increase in temperature and precipitation is not beneficial for Cotton production, and the temperature rise is also dangerous for sugarcane production.

Janjua et al. (2013) explored wheat production under climate change in Pakistan. The research examinedthat geographical location plays a pivotal role in determining the impact of climate change. Wheat crop facesthe positive impact of climate trends in a long and short period. Akramand Hamid (2015) asserted the threat of climate change for economic growth in Pakistan. The research caught

3Loss of water by the plant during an exchange of gases. 
on that temperature has a significant and adverseeffect on gross domestic product and three economic sectors. Simultaneously,adverseinfluence on the agriculture sector is higher than the remaining two sectors of the economy. Rehman et al. (2019) find out the connection between $\mathrm{CO}_{2}$ emission and agriculture productivity in the case of Pakistan. $\mathrm{CO}_{2}$ emission has a positive association with agriculture inputs, energy consumption, and gross domestic product per capita while negative with food grains and seeds.

Climate change has made the agriculture sector prone economically. The major aim is to search out the climate change, environmental degredation, input index and economic growth affectson crops production and highlight some measures for enhancing crops production to cope with climate change. This research-based empirical review will provide robustness of the results, especially on the climate change and crops output in Pakistan's case.

\section{Data Sources, Descriptive Statistics, and Correlation Analysis}

In this research, secondary time series data employ for the period 1977-2016. Temperature, rainfall, Arable land, gross domestic product,and carbon-di-oxide emission data procured from World Development Indicators (WDI). Crops production, fertilizer's off-take, water availability, and improved seeds distribution acquired from Annual Economic Survey of Pakistan(different editions). Table 1 highlight the description of variables briefly while Table 2 and 3 carry out the descriptive statistics and correlation matrix results.

\section{Table 1}

\begin{tabular}{|l|l|l|l|}
\hline Variables Notation & Data Description & Measurement Unit & Expected Sign \\
\hline QG & Crops production & $\begin{array}{l}\text { Percentage of growth } \\
\text { rate }\end{array}$ & $\begin{array}{l}\text { (Dependent } \\
\text { Variable) }\end{array}$ \\
\hline LG & Arable land & $\begin{array}{l}\text { Percentage of growth } \\
\text { rate }\end{array}$ & Positive \\
\hline TG & Average temperature & $\begin{array}{l}\text { Percentage of growth } \\
\text { rate }\end{array}$ & Positive \\
\hline GG & Average rainfall & $\begin{array}{l}\text { Percentage of growth } \\
\text { rate }\end{array}$ & Positive \\
\hline CG & Gross domestic product & $\begin{array}{l}\text { Percentage of growth } \\
\text { rate }\end{array}$ & Positive \\
\hline II & Carbon dioxide emission & $\begin{array}{l}\text { Percentage of growth } \\
\text { rate }\end{array}$ & Positive \\
\hline
\end{tabular}

Source: Author's calculations 
Table 2

\begin{tabular}{|l|l|l|l|l|l|l|l|}
\hline \multicolumn{1}{|l}{ Descriptive Statistics } & QG & LG & TG & RG & CG & GG & II \\
\hline Mean & 2.62 & 0.02 & 0.13 & 3.23 & 5.06 & 14.60 & 5.16 \\
\hline Median & 2.07 & 0.12 & -0.34 & -4.35 & 5.70 & 13.51 & 4.17 \\
\hline Std. Dev. & 6.79 & 2.31 & 2.63 & 29.65 & 4.31 & 5.24 & 8.35 \\
\hline Skewness & 0.44 & -0.26 & -0.04 & 0.90 & -0.22 & 0.96 & 0.60 \\
\hline Kurtosis & 2.79 & 4.54 & 2.51 & 3.41 & 2.59 & 3.78 & 3.48 \\
\hline Jarque-Bera & 1.37 & 4.40 & 0.42 & 5.65 & 0.60 & 7.09 & 2.81 \\
\hline Probability & 0.50 & 0.11 & 0.81 & 0.06 & 0.74 & 0.03 & 0.25 \\
\hline
\end{tabular}

Source: Author Calculation

The mean and median of QG are 2.62 and 2.07, whereas its standard deviation is 6.79. Mean, median, and standard deviations of TG and RG are $0.13,-0.34,2.63$ and 3.23, -4.35, 29.65 respectively. The mean and median of LG and AII are 0.02, 0.12, and 5.16, 4.17, while their standard deviation s are 2.31 and 8.35 correspondingly. The mean and median of CG and GG are 5.06, 5.70 besides 14.60, 13.51 although standard deviations are 4.31 and 5.24. Furthermore, the Mean and median of gross domestic product growth are as well as the standard deviation is $\mathbf{5 . 2 4}$.

QG, RG, GG, and II are positively skewed, while the remaining variables are in the row of negative skewed. LG, RG, GG, and II are greater than three that refer to lepto kurtosis and flat type, although the remaining variables that are less than three are known as platy kurtosis. GG's probability value is near zero (at a $5 \%$ level of significance), so it is not normally distributed while other variables are normally distributed.Jarque-Beraengaged that the sample data is normally distributed.

\section{Table 3}

\begin{tabular}{|c|c|c|c|c|c|c|c|}
\hline \multicolumn{8}{|c|}{ Correlation Matrix } \\
\hline & QG & LG & TG & RG & CG & GG & II \\
\hline QG & 1.00 & & & & & & \\
\hline LG & 0.08 & 1.00 & & & & & \\
\hline TG & 0.20 & -0.06 & 1.00 & & & & \\
\hline RG & 0.13 & -0.19 & -0.33 & 1.00 & & & \\
\hline CG & -0.05 & -0.06 & 0.22 & -0.05 & 1.00 & & \\
\hline GG & -0.03 & 0.14 & -0.02 & -0.09 & 0.09 & 1.00 & \\
\hline II & -0.37 & -0.01 & -0.08 & -0.04 & 0.04 & 0.11 & 1.00 \\
\hline
\end{tabular}

Source: Author's Calculation

The explained variable QG is constructively related, except CG, GG, and II. LG has a negative association with all variables except GG. TG has only a positive connection with CG. RG has a negative liaison with variables, while CG and GG have a progressive link with variables. 
Table 4

\begin{tabular}{|l|l|l|l|l|l|l|l|}
\hline ADF Test for Unit Root & Lag & $\begin{array}{l}\text { Intercept and } \\
\text { Trend }\end{array}$ & Lag & None & Lag & Result \\
\hline LG & -12.669 & 0 & -12.535 & 0 & -12.83 & o & I(0) \\
\hline RG & -12.266 & 0 & -12.135 & 0 & -11.905 & 0 & I(0) \\
\hline TG & -8.203 & 1 & -8.087 & 1 & -8.282 & 1 & I(O) \\
\hline GG & -4.668 & 0 & -4.894 & 0 & -2.457 & 0 & I(O) \\
\hline CG & -2.030 & 1 & -8.404 & 0 & -1.248 & 2 & I(I) \\
\hline II & -6.494 & 0 & -6.214 & 1 & -4.830 & 0 & I(0) \\
\hline QG & -7.897 & 1 & -7.789 & 1 & -5.815 & 1 & I(I) \\
\hline
\end{tabular}

Source: Author's Calculation

Augmented Dickey-Fuller (ADF) test engaged here all the variables are stationary at I (o) excluding carbon-di-oxide and crops production which showed in table 4. So, concluded that the ARDL technique would employ on it.

\section{Model Specification}

In thedesiredmodelclimate change and environmental degradationismeasured with the help of proxy variables temperature, rainfall and carbon dioxide emission respectively.The Input index is the summation of (seeds, water,mechanics,and fertilizer). Crops production growth rate (QG) is the dependent variable while in contrast, land growth rate (LG), average rainfall growth rate (RG), average temperature growth rate (TG), gross domestic product growth rate (GG), carbon-di-oxide emission growth rate (CG), and agriculture input index (II) are independent variables. The long-run equation on the base of ARDL regressed;

$$
\begin{aligned}
\Delta(Q G)_{t}= & \lambda+\sum_{j=1}^{q_{1}} \delta_{1}(Q G)_{t-j}+\sum_{j=0}^{q_{2}} \delta_{2}(L G)_{t-j}+\sum_{j=0}^{q_{3}} \delta_{3}(R G)_{t-j} \\
& +\sum_{j=0}^{q_{4}} \delta_{4}(T G)_{t-j}+\sum_{j=0}^{q_{5}} \delta_{5}(C G)_{t-j}+\sum_{j=0}^{q_{6}} \delta_{6}(G G)_{t-j}+\sum_{j=0}^{q_{7}} \delta_{7}(I I)_{t-j}+\phi_{t}
\end{aligned}
$$

$\delta$ is a long-term parameter, and $\lambda$ is the intercept and $\phi_{t}$ is known as the stochastic term for time series.

The short-run error correction equation is;

$$
\begin{aligned}
\Delta(Q G)_{t}= & \lambda+\sum_{j=1}^{q_{1}} \chi_{1} \Delta(Q G)_{t-j}+\sum_{j=0}^{q_{2}} \chi_{2} \Delta(L G)_{t-j}+\sum_{j=0}^{q_{3}} \chi_{3} \Delta(R G)_{t-j} \\
& +\sum_{j=0}^{q_{4}} \chi_{4} \Delta(T G)_{t-j}+\sum_{j=0}^{q_{5}} \chi_{5} \Delta(C G)_{t-j}+\sum_{j=0}^{q_{6}} \chi_{6} \Delta(G G)_{t-j}+\sum_{j=0}^{q_{7}} \chi_{7} \Delta(I I)_{t-j}+\omega E C M_{t-1}+\phi_{t}
\end{aligned}
$$


$\chi$ is a short-term parameter, $\Delta$ represent as the first difference operator, and $\lambda$ is the intercept and $\phi_{t}$ known as the stochastic term for time series.

\section{Results and Discussion}

Through the bound test, the F-statistics value catches out 5.72 more than upper besides lower bound values results recommended that $\mathrm{H}_{1}$ accepted, referring to co-integration flanked by a long run mention in table 5 .

\section{Table 5}

\begin{tabular}{|l|l|l|}
\hline ARDL Bounds Test & Test Statistic & Test Statistic \\
\hline Test Statistic & F-statistic & F-statistic \\
\hline F-statistic & Significance & Significance \\
\hline Critical Value Bounds & $10 \%$ & $10 \%$ \\
\hline Significance & $5 \%$ & $5 \%$ \\
\hline $10 \%$ & $2.50 \%$ & $2.50 \%$ \\
\hline $5 \%$ & $1 \%$ & $1 \%$ \\
\hline $2.50 \%$ & & \\
\hline $1 \%$ & &
\end{tabular}

Source:Authors' Estimation

After finding out, the co-integration succeeding step is to estimate the long-run association among crops production and independent variables.

\section{Table 6}

\begin{tabular}{|l|l|l|l|l|}
\hline \multicolumn{2}{|l|}{ Long Run Coefficients Results (1, 1, 1, o, 1, o, o) } \\
\hline Variable & Coefficient & Std. Error & t-Statistic & Prob. \\
\hline LG & 2.252 & 0.919 & 2.450 & 0.020 \\
\hline RG & 0.168 & 0.069 & 2.414 & 0.022 \\
\hline TG & 0.961 & 0.431 & 2.226 & 0.033 \\
\hline CG & 0.453 & 0.262 & 1.726 & 0.094 \\
\hline GG & 0.074 & 0.103 & 0.718 & 0.478 \\
\hline II & 0.325 & 0.119 & 2.725 & 0.010 \\
\hline
\end{tabular}

Source: Authors' Estimation

Table 6 explored that the long-run coefficient of LG shows that a $1 \%$ increase in it caused a 2.25\% increase in QG and a statistically significant result supported by Janjua et al. (2010) and Janjua et al.(2013). RG rise $1 \%$ leads to a $0.16 \%$ rise in QG,and it is also statistically significant. The result is compatible withJanjua et al.(2010)and Ahmad et al.(2014).TG shows 1\% increase in it lead to $0.96 \%$ increasein QG,and it is statistically significant. Supported by Xiaoet al.(2007); Ashfaq et al.(2011); Ahmad et al.(2014), and Hanif et al. (2015). CG increase 1\% stands for a $0.45 \%$ rise in QG that is highly significant. The result is supported by Warrick (1988), Mendelsohn et al. (1994), Gedney (2006); Long (2006); Betts et al. (2007). GG rise 1\% refer to the $0.07 \%$ increase in crops production that significantly insignificant. Finally, increase in input index $1 \%$ leads to a $0.3 \%$ increase in crops production, which is significant at 0.01. 
Table 7

\begin{tabular}{|c|c|c|c|c|}
\hline \multicolumn{5}{|c|}{ Short Run Error Correction Results } \\
\hline Variable & Coefficient & Std. Error & t-Statistic & Prob. \\
\hline $\mathrm{D}(\mathrm{LG})$ & 1.264 & 0.551 & 2.293 & 0.029 \\
\hline $\mathrm{D}(\mathrm{RG})$ & 0.090 & 0.042 & 2.139 & 0.040 \\
\hline $\mathrm{D}(\mathrm{TG})$ & 1.013 & 0.417 & 2.425 & 0.021 \\
\hline $\mathrm{D}(\mathrm{GG})$ & 0.078 & 0.109 & 0.717 & 0.478 \\
\hline $\mathrm{D}(\mathrm{CG})$ & -0.240 & 0.225 & -1.064 & 0.295 \\
\hline $\mathrm{D}(\mathrm{II})$ & -0.342 & 0.116 & -2.952 & 0.006 \\
\hline CointEq $(-1)$ & -1.054 & 0.145 & -7.267 & 0.000 \\
\hline \multicolumn{5}{|c|}{ Diagnostic Checks } \\
\hline$R^{2}$ & 0.906 & \multicolumn{2}{|c|}{ LM Test } & $2.108(0.168)$ \\
\hline $\operatorname{Adj} R^{2}$ & 0.834 & \multicolumn{2}{|c|}{ J.B Test } & $2.921(0.232)$ \\
\hline Hetero Test & $0.956(0.519)$ & \multicolumn{2}{|c|}{ Ramsey test } & $0.299(0.594)$ \\
\hline
\end{tabular}

Source:Authors' Estimation

Table 7highlights thatCG and II have the harm Q; solitary in the CG probability value is insignificant. Any shock in a short interval of time is covered by II, LG, RG, and TG. The shows the crops do not observe CG because it is required in the growing phase of plants. ECM value is -1.054 ; it would be more than -1 in line with (Narayan, 2006), whichpostulates that monotonically congregating to straight-line equilibrium pathway, the error correction procedurevaries nearby the long-run value in a diminishingway as soon aswhen this procedure is suffering on the way to end, quickly convergence toward the equilibrium path. The above table shows the diagnostic results of model results shown that model is free from problems like serial correlation, heteroskedasticity, normality and stability issues.

\section{Cusum and CusumsqTest}

The stability of the regression coefficients test shows in figures 4 and 5 the sample period is stable. Because it falls within the transverse lines or critical boundaries at a $5 \%$ level of significance.

\section{Fig. 4Cumulative Sum Test Result}

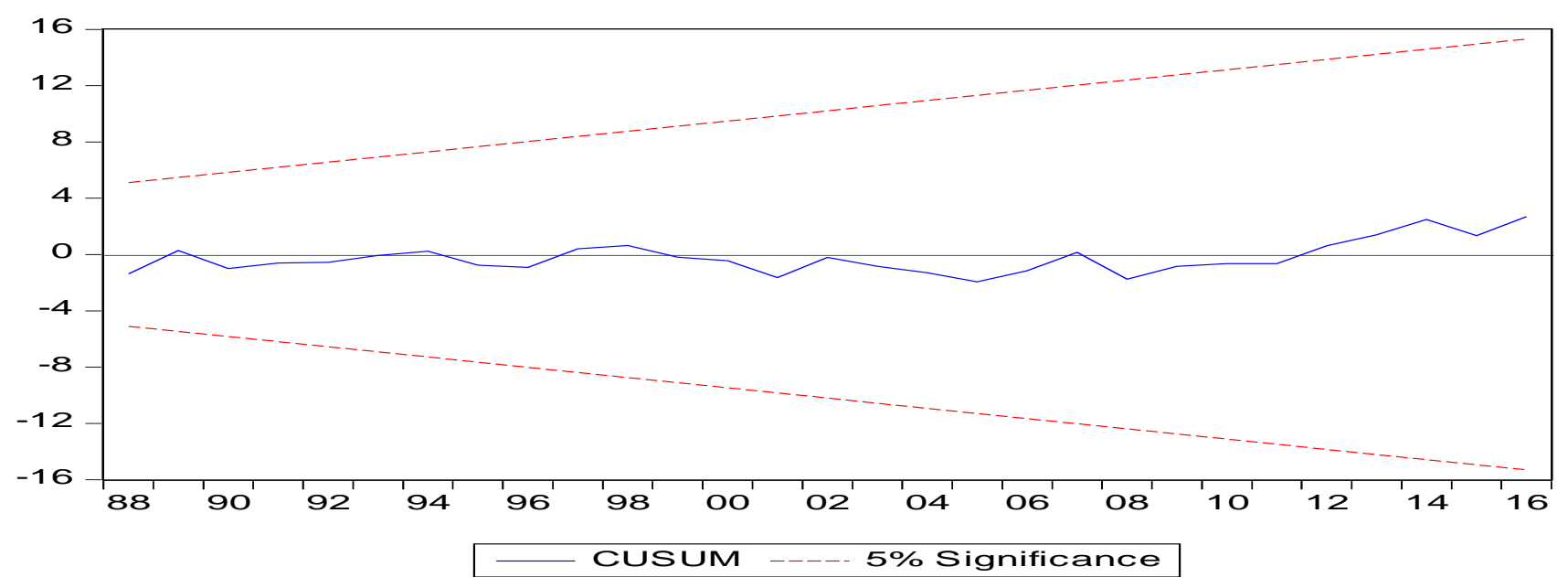




\section{Source: Authors' Estimation}

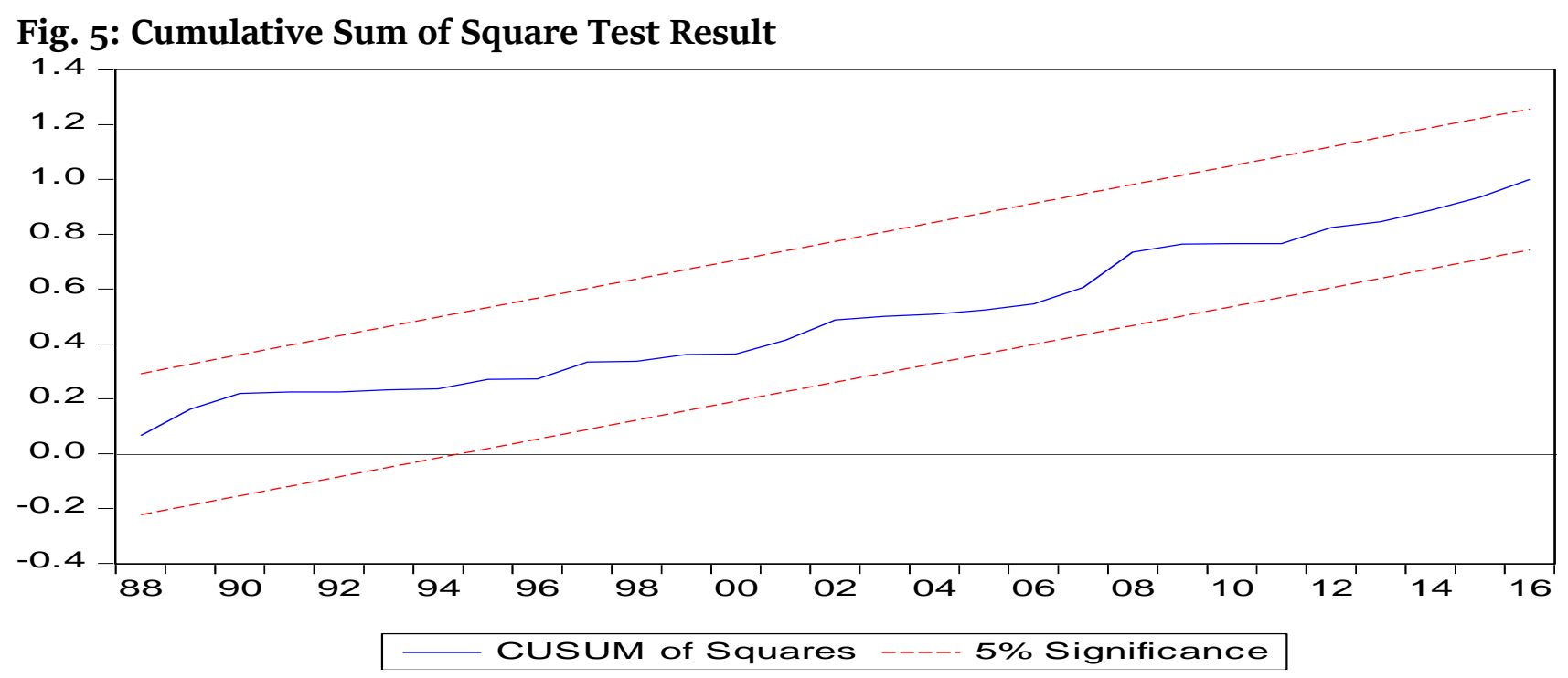

Source:Authors' Estimation

\section{Conclusion and Policy Recommendations}

The present study gives attentiontoexplore climate change,environmental degradation,input index and economic growth influence on cropsproduction inPakistan.Climate change has apositive and negative impact on the agriculture sector; it varies from one region to another.Pakistan is also bearing impact of variation in climate.Agriculture sector is a vital component of the agricultural country's economic system. Industrialization playsa pivotal role in increasing the carbon-dioxide concentration in the atmosphere which lead to environmental degredation.II, LG and RG are most effective while TG is more effective after this CG, and GG is less effective forcrops production under climate change and environmental degradation. Nut Shell, the model, is healthy; three of the test results are valid besides assessing outcomes of the study disclosed that all the employed variables disclose the positive impact on crops production except input index. So, this study finds out some policy suggestions;Agriculture research institutes should develop new seeds and fertilizers varieties besides the supply of water with advanced technologies. The government must take firm steps for agriculture inputs accessibility on subsidizing price at crops cultivation time and should raise awareness about the usage of crops inputs through accessible media sources. The government needs to control water-logging and salinity problems through whichuncultivated land is utilized for Crops production. The governmentslevay heavy taxes on those industrial sectors which produce non environment friendly products.

\section{Reference}

Anderson, R., Bayer, P. E., \& Edwards, D. (2020). Climate change and the need for agricultural adaptation. Current opinion in plant biology, 56, 197-202.

Aaheim, A.A.H., Dokken, T., Wei, T. (2012). Impacts and adaptation to climate change in European economics. Glob. Environ. Change. 22(4), 959-968.

Adams, N.R., Owensby, C. E., Harm, J.M. (2000). The effect of $\mathrm{CO} 2$ enrichment on leaf photosynthetic rates and instantaneous water use efficiency of Andropogongerardii in the tallgrass prairie. Photosynth.65, 121-129.

Ahmad, M., Siftain, H., \& Iqbal, M. (2014). Impact of climate change on wheat productivity in Pakistan: A district-level analysis. Climate Change Working Paper.1. 
Akram, N. \& Hamid, A., (2015). Climate Change: A Threat to the economic growth of Pakistan. Progress in Development studied, 15(1), 73-86.

Ashfaq, M., Zulfiqar, F., Sarwar, I., Quddus, M.A., \&Baig, I., A., (2011). Impact of climate change on wheat productivity in mixed cropping system of Punjab. Soil Environ. 30(2), 110-114.

Bucchignani, E., Zollo, A. L., \&Montesarchio, M. (2021). Analysis of Expected Climate Extreme Variability with Regional Climate Simulations over Napoli Capodichino Airport: A Contribution to a Climate Risk Assessment Framework. Earth, 2(4), 980-996.

Betts, R.A., Boucher, O., Collins M., Cox, P.M., Fallon, N., Gedney, D.L., Hemming, C., Huntingford, C.D., Jones, C.D., Sexton, D.M., \& Webb, M.J. (2007). Projected increase in continental runoff due to plant responses to increasing carbon dioxide, Nature, 448, 1037-1041.

Calzadilla, A., Zhu, T., Rehdanz, K., Tol. R.S.J., \&Ringler, C., (2014). Climate Change and agriculture: Impacts and adaptation option in South Africa, Water Resources and Economics, 5, 24-48.

Dellink, R., Lanzi, E., \& Chateau, J. (2019). The sectoral and regional economic consequences of climate change to 2060. Environmental and resource economics, 72(2), 309-363.

Long, S.P., Anisworth, E.A., Leaky, A.D.B., Nosherger, J., Ort, D.R. (2006). Food for thought: lower than expected crop yield stimulation with rising CO2 concentrations, Science, 312, 1918-1921.

Gedney, N., Cox, P.M., Betts, R.A., Boucher, O., Hunting ford, P.A., \& Stott, P.A., (2006). Detection of direct carbon dioxide in continental river run-off records, Nature, 439, 835-838.

Gornall, J., Betts, R., Burke, E., Clark, R., Camp, J., Willett, K., \& Wiltshire, A., (2010). Implications of climate change for agriculture productivity in the early twenty- first century. Philosophical Transactions; Biological Science, 365(1544), 2973-2989.

Government of Pakistan (2013). 11th Five-year plan 2013-18, Ministry of planning, development and reforms Pakistan.

Government of Pakistan. Pakistan Economic Survey, 2016-17. Ministry of Finance Government of Pakistan.

Hashimoto, K. (2019). Global temperature and atmospheric carbon dioxide concentration. In Global Carbon Dioxide Recycling (pp. 5-17). Springer, Singapore.

Hanif U, Haider S.S., Ahmad R., \& Malik K.A. (2010). Economic Impact of Climate Change on the Agricultural Sector of Punjab. The Pakistan Development Review 49; 4 Part II, 771-798.

Harry, M., Kaiser Susan j. Riha, Dainel S. Wilks, David G. Rossiter, \&RadhaSampath (1993). A Firm Level Analysis of Economic and Agronomic Impacts of Gradual Climate Warming. American Agriculture Economic Association, 75, 387-389.

Ifeanyi-obi C.C., Etuk, U.R., Jike-wai O., (2012). Climate change, Effect and adaptation strategies; Implication for Agriculture Extension System in Nigeria. Greener Journal of Agriculture Science, 2(2), 053-06o.

Intergovernmental Panel on Climate Change (2014). Mitigation of Climate Change. The Fifth Assessment Report of the Intergovernmental Panel on Climate Change. London: Cambridge University Press.

Kirikkaleli, D., \& Adebayo, T. S. (2021). Do public-private partnerships in energy and renewable energy consumption matter for consumption-based carbon dioxide emissions in India?. Environmental Science and Pollution Research, 1-14.

Johnsson, F., Kjärstad, J., \&Rootzén, J. (2019). The threat to climate change mitigation posed by the abundance of fossil fuels. Climate Policy, 19(2), 258-274.

Janjua P.Z, Samad G, Khan, N., (2010). The impact of Climate Change on Wheat Production: A Case Study of Pakistan. The Pakistan Development Review 49; 4 Part II, 799-822.

Janjua P.Z, Samad G, Khan, N., (2013). Climate Change and Wheat Production: An Autoregressive Distributed Lag Model, NJAS - Wageningen Journal of Life Sciences, 68, 13-19. 
Lobell, D. B., Ortiz-Monasterio, J. I., Asner, G. P., Matson, P. A., Naylor, R. L. and Falcon, W. P. (2005). Analysis of wheat yield and climatic trends in Mexico. Field Crops Research, 94(2), 250-256.

Long, S.P., Anisworth, E.A., Leaky, A.D.B., Nosherger, J., Ort, D.R. (2006). Food for thought: lower than expected crop yield stimulation with rising CO2 concentrations, Science, 312, 1918-1921.

Maroco, J.P., Edwards, G.E., Ku, M.S.B. (1999). Photosynthetic acclimation of maise to growth under elevated levels of carbon dioxide. Planta, 210, 115-125.

Mendelsohn, R., Nordhaus W., and Shaw D., (1994). The Impact of Climate Change on Agriculture: A Ricardian Analysis, American Economic Review, 84(4), 753-771.

Narayan, P. K., \& Smyth, R. (2006). What determines migration flows from low-income to high-income countries? An empirical investigation of Fiji-Us migration 19722001. Contemporary Economic Policy, 24(2), 332-342.

Narayan, P.K. \& Narayan, S. (2008). Does military expenditure determine Fiji's exploding debt levels? Defence and Peace Economics, 19(1) 77-87.

O’Neill, B. C., Carter, T. R., Ebi, K., Harrison, P. A., Kemp-Benedict, E., Kok, K., ...\&Pichs-Madruga, R. (2020). Achievements and needs for the climate change scenario framework. Nature climate change, 10(12), 1074-1084.

Pesaran, H. M., Shin, Y., Smith, R. J. (2001). Bounds Testing Approaches to the Analysis of Long-Run Relationships. Journal of Applied Econometrics, 16, 289-326.

Raza, A., Razzaq, A., Mehmood, S. S., Zou, X., Zhang, X., Lv, Y., \& Xu, J. (2019). Impact of climate change on crops adaptation and strategies to tackle its outcome: A review. Plants, 8(2), 34.

Rehman, A., Ozturk, I., \& Zhang, D. (2019). The causal connection between $\mathrm{CO} 2$ emissions and agricultural productivity in Pakistan: empirical evidence from an autoregressive distributed lag bounds testing approach. Applied Sciences, 9(8), 1692.

Shakoor, U., Saboor, A., Ali I., \&Mohsin, A.Q. (2011). Impact of Climate in Agriculture: Empirical Evidence from Arid Region. Pak. J. Agri. Sci., 48 (4), 327-333.

Siddiqui, R., Samad, G., Nasir, \& M., Jail, H.H., (2012). The Impact of Climate Change on Major Agricultural Crops: Evidence from Punjab, Pakistan. The Pakistan Development Review, 51:4, 261-276.

Warrick, R.A. (1988). Carbon Dioxide, Climate Change and agriculture. The Geographical Journal 154:2,221-233.

World Bank, (2008). World Development Report, Oxford University Press, Washington, DC.

Xiao, G., Zhang, Q., Yao, Y., Zhao, H., Wang, R., Bai, H. and Zhang, F. (2008). Impact of recent climatic change on the yield of winter wheat at low and high altitudes in semi-arid North Western China. Agriculture, Ecosystems\&Environment,127(1),37-42. 